\title{
TGF- $\beta$ in inflammatory bowel disease: a key regulator of immune cells, epithelium, and the intestinal microbiota
}

\author{
Sozaburo Ihara $^{1,2} \cdot$ Yoshihiro Hirata $^{2} \cdot$ Kazuhiko Koike $^{2}$
}

Received: 28 April 2017 / Accepted: 7 May 2017/Published online: 22 May 2017

(C) Japanese Society of Gastroenterology 2017

\begin{abstract}
Inflammatory bowel disease (IBD) is defined as chronic intestinal inflammation, and includes ulcerative colitis and Crohn's disease. Multiple factors are involved in the pathogenesis of IBD, and the condition is characterized by aberrant mucosal immune reactions to intestinal microbes in genetically susceptible hosts. Transforming growth factor- $\beta$ (TGF- $\beta$ ) is an immune-suppressive cytokine produced by many cell types and activated by integrins. Active TGF- $\beta$ binds to its receptor and regulates mucosal immune reactions through the TGF- $\beta$ signaling pathway. Dysregulated TGF- $\beta$ signaling is observed in the intestines of IBD patients. TGF- $\beta$ signal impairment in specific cell types, such as T-cells and dendritic cells, results in spontaneous colitis in mouse models. In addition, specific intestinal microbes contribute to immune homeostasis by modulating TGF- $\beta$ production. In this review, we describe the role of TGF- $\beta$ in intestinal immunity, focusing on immune cells, epithelium, and intestinal microbes. In addition, we present potential therapeutic strategies for IBD that target TGF- $\beta$.
\end{abstract}

Keywords Transforming growth factor- $\beta$ - Inflammatory bowel disease $\cdot$ Dendritic cells $\cdot$ Microbiota $\cdot$ Adhesion molecules

Yoshihiro Hirata

hiratay-int@h.u-tokyo.ac.jp

1 Division of Gastroenterology, The Institute for Adult Diseases, Asahi Life Foundation, Tokyo, Japan

2 Department of Gastroenterology, Graduate School of Medicine, The University of Tokyo, 7-3-1 Hongo, Bunkyoku, Tokyo 113-8655, Japan

\author{
Abbreviations \\ IBD Inflammatory bowel disease \\ TGF- $\beta$ Transforming growth factor- $\beta$ \\ UC Ulcerative colitis \\ CD Crohn's disease \\ DCs Dendritic cells \\ TGF $\beta R$ I Transforming growth factor- $\beta$ type I receptor \\ TGF $\beta$ RII Transforming growth factor- $\beta$ type II receptor \\ IELs Intraepithelial lymphocytes
}

\section{Introduction}

Inflammatory bowel disease (IBD) is defined as chronic intestinal inflammation and includes ulcerative colitis (UC) and Crohn's disease (CD). IBD is believed to be caused by complex interactions among host genetic susceptibility, the immune response, environmental triggers, and the luminal microbiota [1,2]. Genome-wide association studies have identified more than 160 loci associated with IBD susceptibility [3], including genes related to intestinal mucosal immune responses, such as NOD2 and ATG16L1 [4, 5]. Regarding environmental triggers, frequent use of antibiotics and improved sanitary conditions (leading to reduced contact with bacteria) are linked to IBD [6]. Changes in the intestinal microbiota are also involved in the pathogenesis of IBD [2, 7]. Inappropriate reactions to commensal intestinal bacteria, as well as an altered bacterial community, contribute to intestinal inflammation [7, 8]. However, the pathogenesis of IBD has not been fully elucidated, and the incidence and prevalence of IBD are increasing worldwide.

Transforming growth factor- $\beta$ (TGF- $\beta$ ) is a pleiotropic cytokine produced by many cell types, including immune 
cells and non-hematopoietic cells, and regulates multiple cellular functions as a suppressor of the immune response, cell proliferation, and oncogenesis. In intestinal immunity, TGF- $\beta$ suppresses inflammatory responses to luminal bacterial antigens and contributes to the induction of immune tolerance $[9,10]$. Smad3, an intracellular signaling protein in the canonical TGF- $\beta$ pathway, is among the loci associated with IBD susceptibility [11]. Impaired TGF- $\beta$ signaling is reported to be associated with the development of intestinal inflammation in experimental models and IBD patients, and compounds that restore TGF- $\beta$ signaling are considered candidate agents for IBD treatment.

Here, we provide an overview of the role of TGF- $\beta$ in IBD, focusing on TGF- $\beta$ production, signaling, and functions as revealed by murine experimental models. Finally, we discuss potential therapeutic strategies for IBD that target TGF- $\beta$.

\section{TGF- $\beta$ in IBD}

\section{TGF- $\beta$ production}

TGF- $\beta$ is abundant in the mammalian intestine. There are three TGF- $\beta$ isoforms in mammals: TGF- $\beta 1$, TGF- $\beta 2$, and TGF- $\beta 3$ [12]. Among them, TGF- $\beta 1$ is the most abundant isoform and its role in intestinal immunity has been investigated extensively $[9,13]$. TGF- $\beta$ is produced by many cell types; e.g., epithelial cells, immune cells, and fibroblasts [13, 14] (Fig. 1a). Although the mechanism underlying modulation of TGF- $\beta$ production in the human intestine remains to be elucidated, TGF- $\beta$ production is upregulated by various factors, such as bacteria, viruses, cytokines, apoptotic cells, and the autocrine/paracrine loop $[15,16]$. A study using laser-captured micro-dissection reported that TGF- $\beta$ expression was higher in the lamina propria than the epithelium in a healthy human colon [9]. TGF- $\beta$ levels in IBD patients have also been evaluated. Babyatsky et al. reported that there was no significant difference in TGF- $\beta 1$ expression in the colonic mucosa of healthy individuals and inactive UC and CD patients [13]. Another study showed that TGF- $\beta 1$ expression in uninvolved mucosa of UC patients was lower than that in normal mucosa [17]. In contrast, TGF- $\beta$ expression was reported to be elevated in active IBD patients, especially in lamina propria lymphocytes [13, 18]. Del Zotto et al. reported that lamina propria lymphocytes isolated from inflamed mucosa of UC patients showed increased TGF- $\beta 1$ production compared to controls when stimulated with CD2 and CD28 [19]. Kanazawa et al. found that TGF- $\beta 2$ and TGF- $\beta 3$ expression was elevated in lamina propria lymphocytes of active UC and CD patients [20]. Moreover, the intestinal epithelium can produce TGF- $\beta$-containing extracellular vesicles [21]. Therefore, TGF- $\beta$ levels are increased in IBD tissues, but this may not be sufficient to counteract the ongoing inflammation.

The association between TGF- $\beta$ level and intestinal strictures in $\mathrm{CD}$ patients has also been investigated. Di Sabatino et al. reported that TGF- $\beta$ expression was elevated in the intestinal mucosa overlying strictures in $C D$ patients [22]. This was due in part to elevated TGF- $\beta$ production by myofibroblasts near the involved intestinal stricture. $\mathrm{Li}$ et al. reported that the active TGF- $\beta$ level was higher in strictured intestinal muscle obtained from surgically resected ilea of $\mathrm{CD}$ patients than in adjacent normal intestinal tissue [23]. IL-6 production by smooth muscle cells was increased in strictured segments of CD patients. Furthermore, IL- 6 activated the STAT3 pathway and promoted TGF- $\beta 1$ production by intestinal smooth muscle cells of CD patients [24].

Serum TGF- $\beta$ levels in IBD patients have also been evaluated. Sambuelli et al. reported that the serum TGF- $\beta 1$ level was higher in naïve active UC patients compared to healthy controls. In addition, the serum TGF- $\beta 1$ concentration increased in response to conventional IBD treatments, suggesting that TGF- $\beta$ is required for suppression of intestinal inflammation in active UC patients $[19,25]$. Contini et al. reported that serum TGF- $\beta 1$ and TGF- $\beta$-expressing-neutrophils increased during granulocyte and monocyte apheresis therapy in patients with active UC [26].

Activation of latent TGF- $\beta$ is important for proper TGF$\beta$ function (Fig. 1a) [27]. First, TGF- $\beta$ is produced and secreted as an inactivate complex with latency-associated peptide. Next, latent TGF- $\beta$ complex is cleaved and activated by serine proteases or metalloproteinases in a TGF$\beta$-isoform-specific manner. In this process, integrins often function as critical co-factors of TGF- $\beta$ activation [28]. Another study reported that $\alpha v \beta 8$ integrin was highly expressed in dendritic cells (DCs) in the human intestine. Indeed, $\alpha v \beta 8$ integrin expression on DCs was upregulated in IBD patients and by microbial stimuli [29]. These data suggest that TGF- $\beta$ production and activation by immune cells, especially DCs, are necessary for inhibiting intestinal inflammation in IBD patients. In contrast, another study showed that TGF- $\beta 1$ activation by integrin $\alpha v \beta 3$ on smooth muscle cells increased collagen production and development of fibrosis in CD patients with stricture [23].

\section{TGF- $\beta$ targets and signaling}

Activated TGF- $\beta$ binds to the TGF- $\beta$ type II receptor (TGFßRII), which is followed by formation of a complex with TGF- $\beta$ type I receptor (TGF $\beta$ RI). The resultant TGF$\beta$ receptor complex activates intracellular signaling through the Smad-dependent canonical and Smad- 


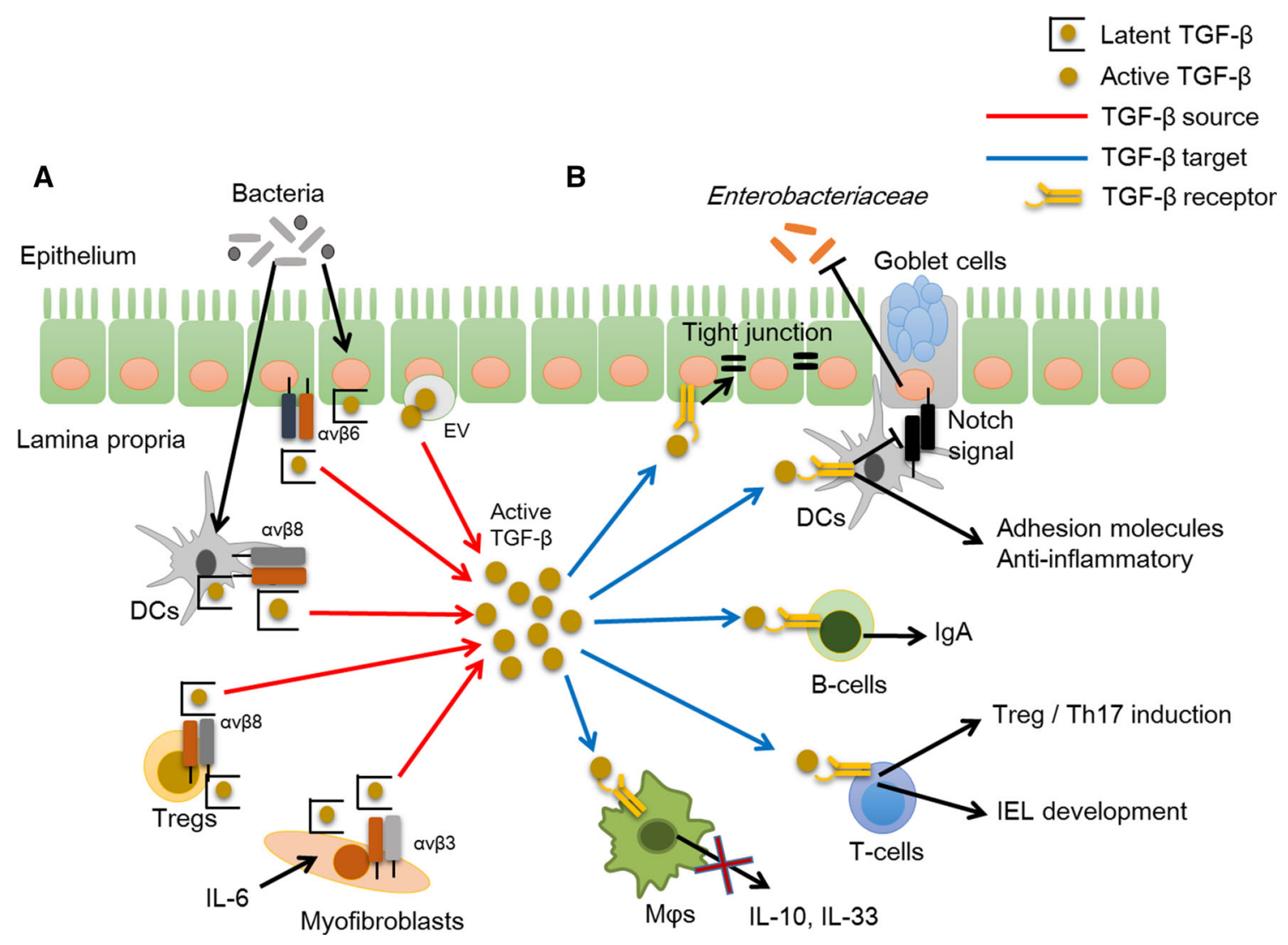

Fig. 1 TGF- $\beta$ sources and TGF- $\beta$ targets in IBD. a TGF- $\beta$ sources in the intestine. TGF- $\beta$ is produced in a latent form or an extracellular vesicle (EV) by immune cells (DCs and Tregs) and non-hematopoietic cells (epithelial cells and fibroblasts). TGF- $\beta$ production is promoted by luminal bacteria, cytokines, and other stimuli. Latent TGF- $\beta$ is activated by integrins such as $\alpha v \beta 3$, $\alpha v \beta 6$, and $\alpha v \beta 8$. b TGF- $\beta$ targets in the intestine. TGF- $\beta$ binds to TGF- $\beta$ receptor on

independent non-canonical pathways. TGF- $\beta$ receptors are expressed by many cell types, including immune cells and epithelial cells, and have multiple functions associated with intestinal immune homeostasis (Fig. 1b). Some patients with Loeys-Dietz syndrome, an autosomal dominant disorder caused by heterozygous mutations of the genes encoding TGF $\beta$ RI or TGF $\beta$ RII ( $T g f b r 1$ or $T g f b r 2$ ), develop early-onset IBD [30, 31].

In the Smad-dependent canonical pathway, phosphorylated Smad2 and Smad3 form a complex with Smad4 and enter the nucleus to regulate the transcription of target genes [32] (Fig. 2). A previous study reported that in healthy individuals, phosphorylation of Smad3 in intestinal T-cells was upregulated compared to that in peripheral T-cells, indicating a role for TGF- $\beta$ signaling in intestinal immune homeostasis [9]. Another study reported that phosphorylation of Smad3 was downregulated in colonic lamina propria mononuclear cells from IBD patients [10]. Smad7 is a downstream target of the TGF- $\beta$ pathway that binds to TGFßRI and acts in a negative-feedback manner immune cells (T-cells, B-cells, DCs, and macrophages) and epithelial cells, which activate the intracellular transduction pathway and contribute to intestinal homeostasis. Intestinal TGF- $\beta$ regulates multiple responses such as Treg and Th17 induction, IEL development, IgA production, modulating adhesion molecule expressions, preventing goblet cell depletion and dysbiosis, inhibiting IL10 and IL33 productions, and enhancing epithelial tight junction expressions

to inhibit the canonical TGF- $\beta$ pathway. Smad7 levels were reported to be elevated in the intestinal mucosa and lamina propria lymphocytes of IBD patients. An elevated Smad7 level resulted in decreased Smad3 phosphorylation and insufficient TGF- $\beta$ signaling, and may be associated with the pathogenesis of IBD $[9,10]$.

\section{Role of TGF- $\beta$ in intestinal immunity}

The intestinal immune system balances immune responses to commensal and harmful antigens in the intestinal lumen to maintain homeostasis. Dysfunction of this system results in intestinal inflammation. Several experimental models of IBD facilitate evaluation of the role of the intestinal immune system, and have identified key regulators and pathways of IBD pathogenesis.

Some mouse strains with inactivation or disruption of TGF- $\beta$ signaling are susceptible to intestinal inflammation and are used to study the pathogenesis of IBD. In 1993, 


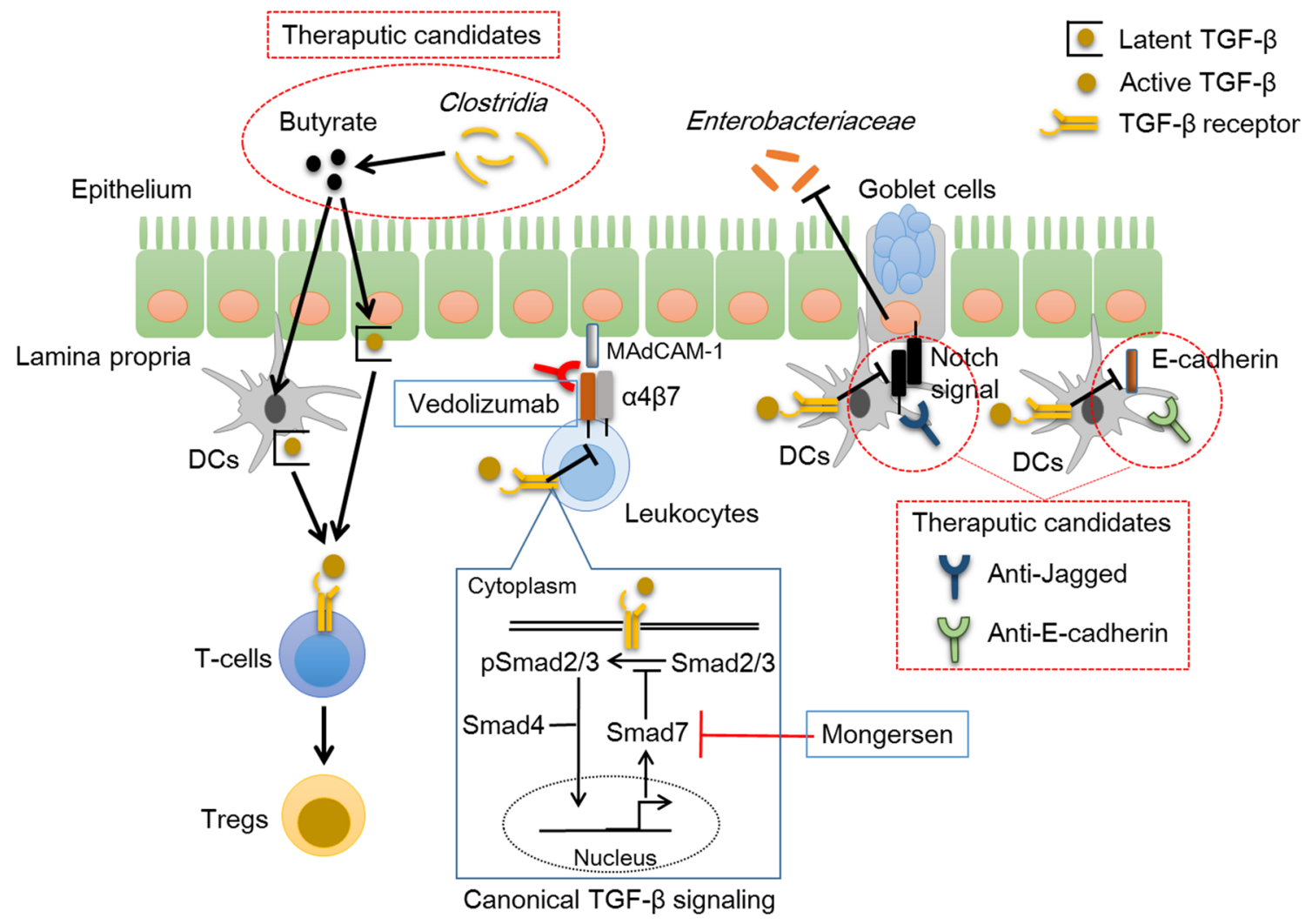

Fig. 2 Therapeutic approaches related to TGF- $\beta$. Therapeutic potentials associated with TGF- $\beta$ signaling in IBD treatments. Oral Smad7 antisense oligonucleotide Mongersen restores Smad-dependent canonical TGF- $\beta$ signaling by inhibiting Smad7, and has been tested in clinical trials. Butyrate mainly derived from Clostridia induces Treg differentiation through TGF- $\beta$ secretion from intestinal

TGF- $\beta 1$ germline-null mice were reported to exhibit massive inflammatory lesions in multiple organs, including the colon, at a few weeks of age [33, 34]. Thereafter, several studies have focused on the specific cellular functions mediated by TGF- $\beta$ signaling. Mice with inactivated TGF$\beta$ signaling due to the presence of a dominant-negative mutant under the control of a cell-specific promoter, or with cell-specific disruption of TGF- $\beta$ signaling by a Crelox recombination, have been used in these studies (Table 1).

In this section, we review the role of TGF- $\beta$ in immune cells and the intestinal epithelium in the pathogenesis of IBD, focusing on experimental mouse models. In addition, we discuss the roles of TGF- $\beta$ and the intestinal microbiota in intestinal immunity.

\section{Immune cells}

T-cells

TGF- $\beta$ regulates multiple immune processes of T-cells. A major function of TGF- $\beta$ signaling in T-cells is to suppress epithelial cells or DCs, which may be a therapeutic target for IBD. Intergin $\alpha 4 \beta 7$ expression on leukocytes is negatively regulated by TGF- $\beta$ signaling, and a $\alpha 4 \beta 7$ inhibitor Vedolizumab is used for IBD therapy. E-cadherin and Notch ligand Jagged1 and Jagged 2 are also negatively regulated by TGF- $\beta$ signaling, and may be therapeutic candidates for IBD treatment

T-cell proliferation and activation through Treg differentiation. Mice with T-cell-targeted deletion of TGF- $\beta$ signaling (CD4-Cre $T g f b r 2^{\mathrm{fl} / \mathrm{fl}}$ ) showed early onset of fatal systemic autoimmunity at 3-5 weeks of age [35, 36]. Furthermore, mice with T-cell-targeted inactivation of TGF- $\beta$ signaling (CD4-dnTGF $\beta$ RII) slowly developed systemic autoimmunity with spontaneous severe colitis at 3-4 months of age [37]. Autoimmunity in both mouse strains was characterized by massive infiltration of lymphocytes and the presence of activated T-cells in multiple organs. CD4-Cre Tgfbr $2^{\mathrm{f} / \mathrm{fl}}$ mice lack TGF $\beta$ RII expression on immature $\mathrm{CD}^{+}$thymocytes and mature peripheral $\mathrm{CD}^{+}{ }^{+}$T-cells, including $\mathrm{CD}^{+}{ }^{+}$Tregs [35]. As a result, CD4-Cre $T g f b r 2^{\mathrm{fl} / \mathrm{fl}}$ mice showed a marked reduction in peripheral $\mathrm{CD}^{+}{ }^{+}$Foxp $^{+}$Tregs. These results suggest that TGF- $\beta$ signaling in T-cells contributes to intestinal immune tolerance, in part by maintenance of the peripheral Treg cell population. Regarding the effect of TGF- $\beta$ production by $\mathrm{CD}^{+}$T-cells on Treg differentiation, mice with $\mathrm{CD}^{+}{ }^{+}$T-cell-targeted deletion of TGF- $\beta 1$ production $\left(\mathrm{CD} 4-\mathrm{CreTg} \mathrm{fbl}^{\mathrm{f} /-}\right.$ ) did not show a reduction in the numbers of peripheral $\mathrm{CD}^{+}{ }^{+}$Foxp $3{ }^{+}$Tregs, although TGF- $\beta 1$ - 
Table 1 Experimental mouse model targeting TGF- $\beta$ signaling

\begin{tabular}{|c|c|c|c|}
\hline Mouse models & Intestinal phenotypes & Other descriptions & References \\
\hline \multicolumn{4}{|l|}{ Global KO models } \\
\hline$T g f b 1^{-1-}$ & $\begin{array}{l}\text { Spontaneous colitis at } 3-4 \text { weeks } \\
\text { of age }\end{array}$ & $\begin{array}{l}\text { Multi-organ autoimmunity with } 60 \% \text { death in } \\
\text { utero }\end{array}$ & {$[33,34,89]$} \\
\hline $\operatorname{Smad} 3^{\mathrm{ex} 2 / \mathrm{ex} 2}$ (Jackson Laboratory) & Susceptible to DSS colitis & Bacteria trigger is required for colitis & [90-92] \\
\hline $\operatorname{Smad} 3^{\mathrm{ex} 8 / \mathrm{ex} 8}$ & Spontaneous colitis & $\begin{array}{l}\text { Develop colonic adenocarcinoma in } \\
6 \text { months of age }\end{array}$ & {$[63]$} \\
\hline Smad $4^{+/-}$ & Susceptible to DSS colitis & $\begin{array}{l}\text { Dysbiosis characterized by increased } \\
\text { Enterococcus faecalis }\end{array}$ & [93] \\
\hline \multicolumn{4}{|l|}{ Cell-specific $\mathrm{KO}$ or Tg models } \\
\hline \multicolumn{4}{|l|}{ Epithelium } \\
\hline ITF-dnTGF $\beta$ RII & Susceptible to DSS colitis & $\begin{array}{l}\text { Generate autoantibodies against intestinal } \\
\text { goblet cells }\end{array}$ & [94] \\
\hline LFABP-PTS4-dnTGF $\beta$ RII & Susceptible to DSS colitis & Delayed wound healing of intestinal injury & {$[95]$} \\
\hline Villin-CreER $T g f b r 2^{\mathrm{fl} / \mathrm{fl}}$ & Susceptible to DSS colitis & $\begin{array}{l}\text { Epithelial TGF } \beta \text { signaling suppresses colitis- } \\
\text { associated tumorigenesis }\end{array}$ & {$[64]$} \\
\hline \multicolumn{4}{|l|}{$\mathrm{T}$ cells } \\
\hline CD2-dnTGF $\beta$ RII & Normal & $\begin{array}{l}\text { Enlarged lymphoid organs with } \mathrm{CD}^{+} \mathrm{T} \text {-cell } \\
\text { expansion }\end{array}$ & [96] \\
\hline CD4-dnTGF $\beta$ RII & $\begin{array}{l}\text { Spontaneous colitis at } 3-4 \text { months } \\
\text { of age }\end{array}$ & Multi-organ autoimmunity & {$[37,42]$} \\
\hline CD4-dnTGF $\beta$ RII; IL1Or2 $2^{-1-}$ & Spontaneous colitis & Antibiotic treatment prevents colitis & {$[80]$} \\
\hline CD4-Cre $T g f b 1^{\mathrm{fl} /-}$ & $\begin{array}{l}\text { Spontaneous colitis over } 4 \text { months } \\
\text { of age }\end{array}$ & $\begin{array}{l}\text { Multi-organ autoimmunity over } 4 \text { months of } \\
\text { age }\end{array}$ & {$[38]$} \\
\hline CD4-Cre $T g f b r 1^{\mathrm{fl} / \mathrm{fl}}$ & Normal? & Reduction in CD8 $\alpha \alpha^{+}$IELs & {$[42,61]$} \\
\hline CD4-Cre $T g f b r 2^{\mathrm{fl} / \mathrm{fl}}$ & $\begin{array}{l}\text { Spontaneous colitis at } 3-5 \text { weeks } \\
\text { of age }\end{array}$ & $\begin{array}{l}\text { More aggressive multi-organ autoimmunity } \\
\text { than CD4-dnTGFßRII }\end{array}$ & {$[35,36]$} \\
\hline CD4-Cre Smad4 $4^{\mathrm{f} / \mathrm{fl}}$ & $\begin{array}{l}\text { Spontaneous colitis at } 9 \text { months of } \\
\text { age }\end{array}$ & $\begin{array}{l}\text { Develop colonic adenocarcinoma in } \\
9-16 \text { months of age }\end{array}$ & {$[97,98]$} \\
\hline CD4-Cre $\beta 1^{\text {glo }}$ & Normal & TGF- $\beta 1$ overexpression in T cells & {$[61]$} \\
\hline cLck-Cre $T g f b r 2^{\mathrm{fl} / \mathrm{fl}}$ & Normal & $\begin{array}{l}\text { Useful strain for understanding post-thymic } \mathrm{T} \\
\text { cell functions }\end{array}$ & {$[43,99]$} \\
\hline cLck-Cre $\operatorname{Smad} 4^{\mathrm{fl} / \mathrm{fl}}$ & $\begin{array}{l}\text { Spontaneous colitis over } 9 \text { months } \\
\text { of age }\end{array}$ & $\begin{array}{l}\text { Develop colonic adenocarcinoma in } \\
9-16 \text { months of age }\end{array}$ & {$[32]$} \\
\hline $\mathrm{CD} 2-\operatorname{Smad} 7^{\mathrm{tg}}$ & Susceptible to DSS colitis & $\begin{array}{l}\text { Does not show autoimmunity over } 18 \text { weeks } \\
\text { of age }\end{array}$ & {$[100,101]$} \\
\hline \multicolumn{4}{|l|}{ B cells } \\
\hline CD19-Cre $T g f b r 2^{\mathrm{f} / / \mathrm{fl}}$ & Normal & $\begin{array}{l}\text { B cell hyperplasia in Peyer's patches with } \\
\text { serum IgA deficiency }\end{array}$ & {$[45,46]$} \\
\hline \multicolumn{4}{|l|}{ Dendritic cells } \\
\hline CD11c-dnTGF $\beta$ RII & Normal & $\begin{array}{l}\text { Does not show autoimmunity and survive } \\
\text { over } 1 \text { year }\end{array}$ & {$[102,103]$} \\
\hline CD11c-Cre $T g f b r 2^{\mathrm{fl} /+}$ & Susceptible to DSS colitis & Antibiotic treatment prevents DSS colitis & {$[50]$} \\
\hline CD11c-Cre $T g f b r 2^{\mathrm{fl} / \mathrm{fl}}$ & $\begin{array}{l}\text { Spontaneous colitis at } 5-14 \text { weeks } \\
\text { of age }\end{array}$ & $\begin{array}{l}\text { Colitogenic microbiota, multi-organ } \\
\text { autoimmunity }\end{array}$ & {$[49,50]$} \\
\hline CD11-Cre $\operatorname{Smad} 2^{\mathrm{fl} / \mathrm{fl}}$ & Ameliorate DSS colitis & Increased Tregs & {$[15]$} \\
\hline \multicolumn{4}{|l|}{ Macrophages } \\
\hline CD68-dnTGF $\beta R I I$ & Susceptible to DSS colitis & $\begin{array}{l}\text { Decreased IL-10 production, and elevated IL- } \\
33^{+} \text {macrophages }\end{array}$ & {$[58]$} \\
\hline Lysm-Cre $T g f b r 2^{f 1 / f 1}$ & Normal & $\begin{array}{l}\text { Myeloid TGF } \beta \text { signaling promotes colitis- } \\
\text { associated tumorigenesis }\end{array}$ & [59] \\
\hline
\end{tabular}

$K O$ knockout, $T G F-\beta$ transforming growth factor- $\beta, T G F \beta R I I$ transforming growth factor- $\beta$ type II receptor, $d n T G F \beta R I I$ dominant-negative transforming growth factor- $\beta$ receptor II, DSS dextran sodium sulfate, Tregs regulatory T cells, IELs intestinal epithelial lymphocytes 
null mice showed lower numbers of Tregs, indicating that TGF- $\beta 1$ produced by cell types other than T-cells contributes to peripheral Treg differentiation [38].

Another function of TGF- $\beta$ in T-cells is Th17 differentiation. TGF- $\beta$ together with IL- 6 was reported to induce differentiation of Th17 cells from naïve $\mathrm{CD}^{+}{ }^{+}$T-cells. Th17 cells produce IL-17 and IFN- $\gamma$, which are necessary for mucosal defense against bacteria, but tend to promote intestinal inflammation [39, 40]. Previous studies showed that Th17 development in the intestine was impaired in TGF- $\beta 1$-null mice and CD4-Cre $T g f b 1^{\mathrm{f} / /-}$ mice $[38,41]$. In contrast, Th17 development was not impaired in CD4-Cre $T g f b r 1^{\mathrm{fl} / \mathrm{fl}}$ mice or CD4-dnTGFßRII mice [42]. Moreover, the role of Th17 cells in intestinal inflammation in TGF- $\beta$ mutant mice is unclear.

A novel function for TGF- $\beta$ in memory $\mathrm{CD} 8^{+}$T-cells was reported recently. cLck-Cre $T g f b r 2^{\mathrm{f} / / \mathrm{fl}}$ mice showed decreased retention of antigen-specific memory $\mathrm{CD} 8^{+}$ T-cells in the intestine, partly due to the defective expression of integrins [43].

\section{B-cells}

TGF- $\beta$ in B-cells mediates IgA class-switch and promotes IgA production [44, 45]. Although mice with deletion of TGF- $\beta$ signaling in B-cells (CD19-Cre $T g f b r 2^{\mathrm{f} / \mathrm{fl}}$ ) did not show signs of autoimmunity or colitis, CD19-Cre $T g f b r 2^{\mathrm{f} / \mathrm{fl}}$ mice showed B-cell hyperplasia in Peyer's patches and decreased B-cell responsiveness with complete serum IgA deficiency $[45,46]$. IgA protects against luminal bacteria by neutralization, enhancing phagocytosis and antigen presentation by DCs. IgA also inhibits bacterial adhesion to the epithelium by blocking surface epitopes of bacteria [47]. IgA production was augmented by the interaction between B-cells and DCs in Peyer's patches through integrin $\alpha v \beta 8$-activated TGF- $\beta$ [48]. This was confirmed by the finding that IgA class-switch by B-cells in Peyer's patches was impaired in CD11c-Cre Itg $b 8^{\mathrm{f} / / \mathrm{fl}}$ mice and by treatment with an $\alpha v \beta 8$-blocking antibody [48].

\section{$D C s$}

Mice with deletion of TGF- $\beta$ signaling in DCs (CD11c-Cre $\left.T g f b r 2^{\mathrm{f} / / \mathrm{fl}}\right)$ developed spontaneous colitis with multiple organ autoimmunity, similar to CD4-Cre $T g f b r 2^{\mathrm{t} / \mathrm{fl}}$ and TGF- $\beta 1$-null mice $[49,50]$. Spontaneous colitis in CD11cCre $T g f b r 2^{\mathrm{ff} / \mathrm{fl}}$ mice was characterized by loss of goblet cells with lymphocytic infiltration and systemic autoimmunity due to altered Treg differentiation, activated T-cells and B-cells, and increased secretion of inflammatory cytokines such as TNF- $\alpha$ and IFN- $\gamma$ [49]. We also examined colitis in CD11c-Cre $T g f b r 2^{\mathrm{f} / / \mathrm{fl}}$ mice and found enhanced expression of Notch ligands on DCs, goblet cell depletion, a thinner mucus layer, and dysbiosis (Fig. 1b) [50]. These results reveal the critical role played by TGF- $\beta$ signaling by DCs in colonic homeostasis.

DCs are also important as a source and activator of TGF- $\beta$ in the intestine. Intestinal DCs produce TGF- $\beta$ and IL-10, which are major suppressors of intestinal immunity [51]. Previous reports showed that $\mathrm{CD} 103^{+}$tolerogenic DCs produce TGF- $\beta$ and retinoic acid, which contributes to Treg differentiation $[52,53]$. Intestinal DCs also contribute to TGF- $\beta$ activation. Mice with DC-specific deletion of integrin $\beta 8\left(\mathrm{CD} 11 \mathrm{c}-\mathrm{Cre} \operatorname{Itg} b 8^{\mathrm{fl} / \mathrm{fl}}\right)$ developed spontaneous colitis due to a lack of TGF- $\beta$ activation by $\alpha \mathrm{v} \beta 8$ in DCs, whereas T-cell-specific deletion of integrin $\beta 8$ (CD4-Cre $\left.\operatorname{Itg} b 8^{\mathrm{f} / \mathrm{f}}\right)$ did not result in the development of colitis [54].

In contrast to $\mathrm{CD}_{103^{+}}$tolerogenic DCs, E-cadherin ${ }^{+}$ inflammatory DCs promoted intestinal inflammation through aberrant IL-17 production by $\mathrm{CD}^{+}{ }^{+} \mathrm{T}$-cells [55]. E-cadherin is an adhesion molecule expressed in the intestinal epithelium, and also by subsets of monocytes, DCs, and macrophages [55-57]. E-cadherin ${ }^{+}$DCs were increased in a T-cell-transfer murine colitis model, especially in the inflamed intestine. Indeed, adoptive transfer of E-cadherin ${ }^{+}$BMDCs into T-cell-restored Rag1 ${ }^{-/-}$mice exacerbated colitis, with an increased Th17 response [55]. TGF- $\beta$-deficient mice (DO11.10 $\mathrm{Tg}_{\mathrm{fbl}} \mathrm{C}^{--}$) showed an increased frequency of E-cadherin ${ }^{+}$DCs, indicating that TGF- $\beta$ limits the accumulation of E-cadherin on DCs [55]. However, the molecular mechanisms underlying exacerbation of colitis by E-cadherin ${ }^{+}$DCs are unclear, and data regarding E-cadherin expression in intestinal DCs from IBD patients are lacking.

\section{Macrophages}

Mice with TGF- $\beta$ signaling inactivation in macrophages (CD68-dnTGFßRII) did not develop spontaneous colitis, but exhibited susceptibility to DSS-induced colitis with reduced IL-10 production [58]. TGF- $\beta$ signaling in macrophages suppressed IL-33 production and protected against intestinal inflammation [58, 59]. It has also been reported that TGF- $\beta$ downregulates the expression of innate response receptors, such as that for LPS (CD14), on human intestinal macrophages. This contributed to the development of an "inflammatory anergy" macrophage phenotype, which is characterized by a lack of proinflammatory cytokine production under inflammatory stimuli but retention of phagocytic and bactericidal activity [60].

\section{Intraepithelial lymphocytes (IELs)}

TGF- $\beta$ production and signaling by T-cells are important for IEL development [61]. IELs reside in the intestinal epithelial layer and play a role in mucosal defense. The 
majority of TCR $\alpha \beta^{+}$IELs are divided into subsets expressing $\mathrm{CD} 8 \alpha \alpha^{+}$or $\mathrm{CD} 8 \alpha \beta^{+}$[62]. A previous study demonstrated that $\mathrm{Tgfb} 1^{-/-}, \mathrm{Smad} 3^{\mathrm{ex} 8 / \mathrm{ex} 8}$, and CD4Cre $T g f b r l^{\mathrm{fl} / \mathrm{fl}}$ mice showed reduced numbers of TCR $\alpha \beta^{+} \mathrm{CD} 8 \alpha \alpha^{+}$IELs, whereas mice with TGF- $\beta 1$-overexpressing T-cells (CD4-Cre $\beta 1^{\text {glo }}$ ) showed increased numbers of TCR $\alpha \beta^{+} \mathrm{CD} 8 \alpha \alpha^{+}$IELs, suggesting that TGF- $\beta$ controls the generation and retention of CD8 $\alpha \alpha^{+}$IELs via CD8 $\alpha$ expression [61, 63]. Another study investigated TGF- $\beta$ production by TCR $\alpha \beta^{+} \mathrm{CD} 8 \alpha \beta^{+}$IELs. Upon infection by Toxoplasma gondii, TGF- $\beta$ produced by IELs interacted with the lamina propria $\mathrm{CD} 4^{+} \mathrm{T}$-cells and reduced intestinal inflammation by downregulating IFN- $\gamma$ production [62].

\section{Epithelium and extracellular matrix}

Previous studies have unraveled the roles of TGF- $\beta$ in intestinal epithelial homeostasis associated with mucosal integrity, wound healing, and consequent fibrosis. Mouse models with disruption of TGF- $\beta$ signaling in the intestinal epithelium (such as Villin-CreER $T g f b r 2^{\mathrm{fl} / \mathrm{fl}}$ mice) showed increased susceptibility to DSS-induced colitis [64], although spontaneous colitis did not occur in these strains, in contrast to TGF- $\beta 1$-null mice (Table 1 ). A recent study revealed that TGF- $\beta$-containing extracellular vesicles released by epithelial cells induced Treg differentiation and inhibited colitis by binding to $\mathrm{EpCAM}^{+}$epithelial cells [21]. Therefore, epithelial cells also play an important role in immune homeostasis in a TGF- $\beta$-dependent manner.

TGF- $\beta$ modulates the barrier function of the epithelium by regulating the expression levels of tight-junction proteins and adhesion molecules [65]. A previous in vitro study using an intestinal monolayer cell line reported that TGF- $\beta$ enhanced intestinal epithelial barrier function by inducing production of the tight junction protein Claudin-1, and by preventing the pathogenic bacteria-induced reduction of levels of the tight-junction proteins Claudin-2, Occludin, and ZO-1 [66].

As wound healing progresses in injured tissues, the provisional extracellular matrix is replaced by a newly formed matrix, which is rich in collagen synthesized by fibroblasts migrating into the wound [67]. The extracellular matrix is composed of collagens, non-collagenous glycoproteins (including fibronectin) and proteoglycans. In CD patients, chronic transmural intestinal inflammation can result in intestinal fibrosis and fistula, which require surgical resection [68]. Intestinal strictures in CD patients, which are usually caused by chronic inflammation and healing, were associated with an increased TGF- $\beta$ transcript level and excessive accumulation of extracellular matrix proteins, such as collagens and fibronectin [22, 69]. Myofibroblasts isolated from intestinal strictures of $\mathrm{CD}$ patients overexpressed collagen III, and TGF- $\beta 1$ promoted collagen III production by myofibroblasts [69]. Moreover, pirfenidone, an anti-fibrogenic drug used for the treatment of fibrotic diseases, suppressed intestinal fibrosis in a DSSinduced colitis model by inhibiting TGF- $\beta$ signaling $[70,71]$.

\section{Microbiota}

The intestinal lumen harbors trillions of microbes of diverse taxa, including both commensal and harmful bacteria; this microbial ecosystem is termed the microbiota. The microbiota plays a mutualistic role in intestinal homeostasis by modulating the host immune systems through their own physiological processes and metabolites [72]. Some commensal bacterial strains exert an immunomodulatory effect in a manner involving TGF- $\beta$.

\section{Clostridium}

Clostridium is a major genus in the intestinal microbiota and includes several commensal taxa. Microbial transplantation experiments using germ-free mice showed that some strains of Clostridium cluster IV and XIVa induced TGF- $\beta$ release from the intestinal epithelium and Treg differentiation [73-75]. Clostridium cluster IV and XIVa were reported to be less abundant in IBD patients than in healthy controls [76]. Another study showed that administration of Clostridium butyricum (cluster I) as a probiotic [77] promoted Treg differentiation through TGF- $\beta 1$ produced by lamina propria DCs in a TGF- $\beta$-Smad and TLRERK-AP1 pathway-dependent manner [15].

\section{Bacteroides}

Bacteroides is a Gram-negative, obligate anaerobic bacterial genus that comprises a considerable proportion of the normal intestinal flora. The abundance of the genus Bacteroides is decreased in IBD patients compared to healthy controls [78]. Bacteroides fragilis was reported to induce Treg differentiation [79]. B. fragilis monocolonization of germ-free mice restored TGF- $\beta 2$ and IL-10 production by Tregs and elicited mucosal tolerance in the intestine. This TGF- $\beta 2$ production was dependent on polysaccharide A of B. fragilis [79]. In contrast, another study reported that luminal commensal bacteria, such as Bacteroides vulgatus and Bacteroides thetaiotaomicron, are responsible for the development of colitis in mice with T-cell-specific inactivation of TGF- $\beta$ and IL-10 signaling [80]. Importantly, these two Bacteroides species did not induce colitis in hosts with intact TGF- $\beta$ signaling, suggesting that TGF- $\beta$ signaling suppresses the proinflammatory effects of commensal bacteria. 


\section{Enterobacteriaceae}

The commensal Gram-negative Enterobacteriaceae comprise a minor proportion of the intestinal microbiota; however, overgrowth of Enterobacteriaceae occurs in most colitis models and IBD patients, and may be associated with the promotion of intestinal inflammation [8, 72, 81]. The mechanisms underlying the induction and promotion of colitis by Enterobacteriaceae are unclear; however, increased oxidative stress due to, for example, increased ROS and NOS generation caused by bacterial stimulation of TLRs, contributes to dysbiosis [82, 83]. We previously reported overgrowth of Enterobacteriaceae in CD11c-cre $T g f b r 2^{\mathrm{f} / / \mathrm{fl}}$ mice. TGF- $\beta$ signaling of DCs was essential for control of the luminal Enterobacteriaceae through the interactions with epithelial cells [50].

\section{Potential therapeutic strategies targeting TGF- $\beta$}

Anti-TNF- $\alpha$ antibodies have for more than 15 years been used to treat IBD. Our increasing understanding of the role of immune regulation in the pathogenesis of IBD has resulted in the proposal of novel therapeutic options for IBD [84]. As described above, the importance of TGF- $\beta$ signaling in IBD pathogenesis is becoming increasingly apparent. In this section, we focus on the therapeutic potential of TGF- $\beta$ signaling.

An oral Smad7 antisense oligonucleotide (Mongersen, GED-0301) was reported to restore TGF- $\beta$ signaling in the intestine of CD patients, an effect mediated by degradation of Smad7 mRNA [85]. In a preclinical trial, Monteleone et al. showed that inhibition of Smad7 by a specific antisense oligonucleotide restored TGF- $\beta 1$-induced Smad3 phosphorylation in lamina propria mononuclear cells of UC and CD patients [10]. In a phase I trial of Mongersen, 15 patients with active $\mathrm{CD}$ received one of three doses of Mongersen (40, 80, or $160 \mathrm{mg}$ ), and the results demonstrated its safety and tolerability [86]. In a phase II trial, 166 patients with active $\mathrm{CD}$ were randomly assigned to receive one of three doses of Mongersen (10, 40, or $160 \mathrm{mg}$ ) or placebo $[85,87]$. The primary outcome of this phase II trial, which was the clinical remission rate at day 15 of Mongersen treatment, was achieved in 55 and $65 \%$ of patients in the 40 and $160 \mathrm{mg}$ Mongersen groups, respectively, compared with $10 \%$ for the placebo group. Most adverse events were related to complications and symptoms of $\mathrm{CD}$. This trial demonstrated a benefit in terms of the clinical remission rate, as well as the safety and tolerability, of Mongersen in active CD patients [87]. Further studies involving a large population of $\mathrm{CD}$ patients are needed to confirm the safety and efficacy of Mongersen.
Other than Mongersen, no drug that targets TGF- $\beta$ signaling to ameliorate IBD has been subjected to a clinical trial. However, therapeutic approaches related to TGF- $\beta$ have potential for IBD treatment (Fig. 2). Because impaired TGF- $\beta$ signaling in IBD patients is associated with reduced Treg differentiation, approaches to promote Treg differentiation should also be considered. A previous study reported that butyrate, a short-chain fatty acid bacterial metabolite produced mainly by commensal Clostridium species, was associated with Treg induction [73]. Therefore, administration of butyrate or butyrateproducing Clostridium species may have therapeutic potential for IBD.

TGF- $\beta$ regulates the expression of adhesion molecules, such as integrins and E-cadherin, and Notch ligands in lymphocytes, which are also therapeutic targets for IBD. TGF- $\beta$ downregulates the expression of integrin $\alpha 4 \beta 7$, E-cadherin, and Jagged1/2 [43, 50, 55]. Expression of these factors may be upregulated in TGF- $\beta$-signaling-impaired IBD patients, and so agents that suppress expression of these factors may have therapeutic potential. Although anti-E-cadherin and Jagged $1 / 2$ have not been subjected to clinical trials, anti- $\alpha 4 \beta 7$ treatment has been used in clinical practice. Vedolizumab is the first gut-selective humanized $\alpha 4 \beta 7$ inhibitor, and functions by blocking the interaction between $\alpha 4 \beta 7$ on gut-homing T-cells and MAdCAM- 1 in the epithelium [88]. Vedolizumab has been approved for clinical IBD therapy in the USA and Europe. Therefore, factors involved in TGF- $\beta$ signaling may also have therapeutic potential, which should be the subject of further work.

\section{Concluding remarks}

The studies included in this review suggest that TGF- $\beta$ is involved in the maintenance of intestinal homeostasis through modulating the functions of immune cells, the epithelium, and the luminal microbiota, which are associated with the pathogenesis of IBD. Studies using samples from IBD patients have shown that the TGF- $\beta$ level is elevated in active IBD patients, but activation of TGF- $\beta$ signaling is insufficient to suppress active IBD. Studies using mouse models have shown that TGF- $\beta$ signaling by T-cells or DCs is important for Treg differentiation and epithelial homeostasis, to protect against the development of spontaneous colitis. Further studies using such mouse models will enhance our understanding of the role of TGF$\beta$ signaling in IBD, and likely result in identification of novel therapeutic targets associated with TGF- $\beta$ signaling. Recent clinical studies showing the efficacy of TGF- $\beta$ signal restoration in treatment of active $C D$ will drive targeting of TGF- $\beta$ signaling in IBD treatment. Therapies 
that influence the microbiota to modulate intestinal TGF- $\beta$ production, and those targeting TGF- $\beta$-related adhesion molecules can be the next candidates for IBD treatments.

Acknowledgments This study was supported by a grant from Asahi Life Foundation.

\section{Compliance with ethical standards}

Conflict of interest The authors declare that there are no conflicts of interest.

\section{References}

1. Abraham C, Cho JH. Inflammatory bowel disease. N Engl J Med. 2009;361:2066-78.

2. Xavier RJ, Podolsky DK. Unravelling the pathogenesis of inflammatory bowel disease. Nature. 2007;448:427-34.

3. Jostins L, Ripke S, Weersma RK, et al. Host-microbe interactions have shaped the genetic architecture of inflammatory bowel disease. Nature. 2012;491:119-24.

4. Hugot JP, Chamaillard M, Zouali H, et al. Association of NOD2 leucine-rich repeat variants with susceptibility to Crohn's disease. Nature. 2001;411:599-603.

5. Hampe J, Franke A, Rosenstiel P, et al. A genome-wide association scan of nonsynonymous SNPs identifies a susceptibility variant for Crohn disease in ATG16L1. Nat Genet. 2007;39:207-11.

6. Bernstein CN, Shanahan F. Disorders of a modern lifestyle: reconciling the epidemiology of inflammatory bowel diseases. Gut. 2008;57:1185-91.

7. Sartor RB. Microbial influences in inflammatory bowel diseases. Gastroenterology. 2008;134:577-94.

8. Garrett WS, Gallini CA, Yatsunenko T, et al. Enterobacteriaceae act in concert with the gut microbiota to induce spontaneous and maternally transmitted colitis. Cell Host Microbe. 2010;8:292-300.

9. Di Sabatino A, Pickard KM, Rampton D, et al. Blockade of transforming growth factor beta upregulates T-box transcription factor T-bet, and increases $\mathrm{T}$ helper cell type 1 cytokine and matrix metalloproteinase- 3 production in the human gut mucosa. Gut. 2008;57:605-12.

10. Monteleone G, Kumberova A, Croft NM, et al. Blocking Smad7 restores TGF-beta1 signaling in chronic inflammatory bowel disease. J Clin Investig. 2001;108:601-9.

11. Lees CW, Barrett JC, Parkes M, et al. New IBD genetics: common pathways with other diseases. Gut. 2011;60:1739-53.

12. Massagué J. The transforming growth factor-beta family. Annu Rev Cell Biol. 1990;6:597-641.

13. Babyatsky MW, Rossiter G, Podolsky DK. Expression of transforming growth factors alpha and beta in colonic mucosa in inflammatory bowel disease. Gastroenterology. 1996;110:975-84.

14. Letterio JJ, Roberts AB. Regulation of immune responses by TGF-beta. Annu Rev Immunol. 1998;16:137-61.

15. Kashiwagi I, Morita R, Schichita T, et al. Smad2 and Smad3 inversely regulate TGF- $\beta$ autoinduction in Clostridium butyricum-activated dendritic cells. Immunity. 2015;43:65-79.

16. Torchinsky MB, Garaude J, Martin AP, et al. Innate immune recognition of infected apoptotic cells directs $\mathrm{T}(\mathrm{H}) 17$ cell differentiation. Nature. 2009;458:78-82.

17. Chowdhury A, Fukuda R, Fukumoto S. Growth factor mRNA expression in normal colorectal mucosa and in uninvolved mucosa from ulcerative colitis patients. J Gastroenterol. 1996;31:353-60.

18. McCabe RP, Secrist H, Botney M, et al. Cytokine mRNA expression in intestine from normal and inflammatory bowel disease patients. Clin Immunol Immunopathol. 1993;66:52-8.

19. Del Zotto B, Mumolo G, Pronio AM, et al. TGF-beta1 production in inflammatory bowel disease: differing production patterns in Crohn's disease and ulcerative colitis. Clin Exp Immunol. 2003;134:120-6.

20. Kanazawa S, Tsunoda T, Onuma E, et al. VEGF, basic-FGF, and TGF-beta in Crohn's disease and ulcerative colitis: a novel mechanism of chronic intestinal inflammation. Am J Gastroenterol. 2001;96:822-8.

21. Jiang L, Shen Y, Guo D, et al. EpCAM-dependent extracellular vesicles from intestinal epithelial cells maintain intestinal tract immune balance. Nat Commun. 2016;7:13045.

22. Di Sabatino A, Jackson CL, Pickard KM, et al. Transforming growth factor beta signalling and matrix metalloproteinases in the mucosa overlying Crohn's disease strictures. Gut. 2009;58:777-89.

23. Li C, Flynn RS, Grider JR, et al. Increased activation of latent TGF- $\beta 1$ by $\alpha \mathrm{V} \beta 3$ in human Crohn's disease and fibrosis in TNBS colitis can be prevented by cilengitide. Inflamm Bowel Dis. 2013;19:2829-39.

24. Li C, Iness A, Yoon J, et al. Noncanonical STAT3 activation regulates excess TGF- $\beta 1$ and collagen I expression in muscle of stricturing Crohn's disease. J Immunol. 2015;194:3422-31.

25. Sambuelli A, Diez RA, Sugai E, et al. Serum transforming growth factor-betal levels increase in response to successful anti-inflammatory therapy in ulcerative colitis. Aliment Pharmacol Ther. 2000;14:1443-9.

26. Contini P, Negrini S, Bodini G, et al. Granulocytes and monocytes apheresis induces upregulation of TGF $\beta 1$ in patients with active ulcerative colitis: a possible involvement of soluble HLAI. J Clin Apher. 2017;32:49-55.

27. Massagué J. TGF $\beta$ signalling in context. Nat Rev Mol Cell Biol. 2012;13:616-30.

28. Jenkins G. The role of proteases in transforming growth factorbeta activation. Int J Biochem Cell Biol. 2008;40:1068-78.

29. Fenton TM, Kelly A, Shuttleworth EE, et al. Inflammatory cues enhance TGF $\beta$ activation by distinct subsets of human intestinal dendritic cells via integrin $\alpha v \beta 8$. Mucosal Immunol. 2017;10:624-34.

30. Naviglio S, Arrigo S, Martelossi S, et al. Severe inflammatory bowel disease associated with congenital alteration of transforming growth factor beta signaling. J Crohns Colitis. 2014;8:770-4.

31. Loeys BL, Schwarze U, Holm T, et al. Aneurysm syndromes caused by mutations in the TGF-beta receptor. N Engl J Med. 2006;355:788-98.

32. Johnston CJ, Smyth DJ, Dresser DW, et al. TGF- $\beta$ in tolerance, development and regulation of immunity. Cell Immunol. 2016;299:14-22.

33. Shull MM, Ormsby I, Kier AB, et al. Targeted disruption of the mouse transforming growth factor-beta 1 gene results in multifocal inflammatory disease. Nature. 1992;359:693-9.

34. Kulkarni AB, Huh CG, Becker D, et al. Transforming growth factor beta 1 null mutation in mice causes excessive inflammatory response and early death. Proc Natl Acad Sci USA. 1993;90:770-4.

35. Li MO, Sanjabi S, Flavell RA. Transforming growth factor-beta controls development, homeostasis, and tolerance of $\mathrm{T}$ cells by regulatory $\mathrm{T}$ cell-dependent and -independent mechanisms. Immunity. 2006;25:455-71.

36. Marie JC, Liggitt D, Rudensky AY. Cellular mechanisms of fatal early-onset autoimmunity in mice with the $\mathrm{T}$ cell-specific 
targeting of transforming growth factor-beta receptor. Immunity. 2006;25:441-54.

37. Gorelik L, Flavell RA. Abrogation of TGFbeta signaling in T cells leads to spontaneous $\mathrm{T}$ cell differentiation and autoimmune disease. Immunity. 2000;12:171-81.

38. Li MO, Wan YY, Flavell RA. T cell-produced transforming growth factor-betal controls $\mathrm{T}$ cell tolerance and regulates Th1and Th17-cell differentiation. Immunity. 2007;26:579-91.

39. Goto Y, Panea C, Nakato G, et al. Segmented filamentous bacteria antigens presented by intestinal dendritic cells drive mucosal Th17 cell differentiation. Immunity. 2014;40:594-607.

40. Ivanov II, Atarashi K, Manel N, et al. Induction of intestinal Th17 cells by segmented filamentous bacteria. Cell. 2009; 139:485-98

41. Mangan PR, Harrington LE, O'Quinn DB, et al. Transforming growth factor-beta induces development of the $\mathrm{T}(\mathrm{H}) 17$ lineage. Nature. 2006;441:231-4.

42. Ghoreschi K, Laurence A, Yang XP, et al. Generation of pathogenic $\mathrm{T}(\mathrm{H}) 17$ cells in the absence of TGF- $\beta$ signalling. Nature. 2010;467:967-71.

43. Zhang N, Bevan MJ. Transforming growth factor- $\beta$ signaling controls the formation and maintenance of gut-resident memory $\mathrm{T}$ cells by regulating migration and retention. Immunity. 2013;39:687-96.

44. Ruane D, Chorny A, Lee H, et al. Microbiota regulate the ability of lung dendritic cells to induce IgA class-switch recombination and generate protective gastrointestinal immune responses. J Exp Med. 2016;213:53-73.

45. Cazac BB, Roes J. TGF-beta receptor controls B cell responsiveness and induction of IgA in vivo. Immunity. 2000;13:443-51.

46. Roes J, Choi BK, Cazac BB. Redirection of B cell responsiveness by transforming growth factor beta receptor. Proc Natl Acad Sci USA. 2003;100:7241-6.

47. Kubinak JL, Round JL. Do antibodies select a healthy microbiota? Nat Rev Immunol. 2016;16:767-74.

48. Reboldi A, Arnon TI, Rodda LB, et al. IgA production requires B cell interaction with subepithelial dendritic cells in Peyer's patches. Science. 2016;352:aaf4822.

49. Ramalingam R, Larmonier CB, Thurston RD, et al. Dendritic cell-specific disruption of TGF- $\beta$ receptor II leads to altered regulatory $\mathrm{T}$ cell phenotype and spontaneous multiorgan autoimmunity. J Immunol. 2012;189:3878-93.

50. Ihara S, Hirata $Y$, Serizawa T, et al. TGF- $\beta$ signaling in dendritic cells governs colonic homeostasis by controlling epithelial differentiation and the luminal microbiota. $\mathrm{J}$ Immunol. 2016;196:4603-13.

51. Guéry L, Hugues S. Tolerogenic and activatory plasmacytoid dendritic cells in autoimmunity. Front Immunol. 2013;4:59.

52. Coombes JL, Siddiqui KR, Arancibia-Cárcamo CV, et al. A functionally specialized population of mucosal CD $103^{+}$DCs induces Foxp $3^{+}$regulatory T cells via a TGF-beta and retinoic acid-dependent mechanism. J Exp Med. 2007;204:1757-64.

53. Sun CM, Hall JA, Blank RB, et al. Small intestine lamina propria dendritic cells promote de novo generation of Foxp3 T reg cells via retinoic acid. J Exp Med. 2007;204:1775-85.

54. Travis MA, Reizis B, Melton AC, et al. Loss of integrin alpha(v)beta8 on dendritic cells causes autoimmunity and colitis in mice. Nature. 2007;449:361-5.

55. Siddiqui KR, Laffont S, Powrie F. E-cadherin marks a subset of inflammatory dendritic cells that promote $\mathrm{T}$ cell-mediated colitis. Immunity. 2010;32:557-67.

56. Van den Bossche J, Malissen B, Mantovani A, et al. Regulation and function of the E-cadherin/catenin complex in cells of the monocyte-macrophage lineage and DCs. Blood. 2012;119: 1623-33.
57. Van den Bossche J, Van Ginderachter JA. E-cadherin: from epithelial glue to immunological regulator. Eur J Immunol. 2013;43:34-7.

58. Rani R, Smulian AG, Greaves DR, et al. TGF- $\beta$ limits IL-33 production and promotes the resolution of colitis through regulation of macrophage function. Eur $\mathrm{J}$ Immunol. 2011;41:2000-9.

59. Li J, Liu Y, Wang B, et al. Myeloid TGF- $\beta$ signaling contributes to colitis-associated tumorigenesis in mice. Carcinogenesis. 2013;34:2099-108.

60. Smythies LE, Sellers M, Clements RH, et al. Human intestinal macrophages display profound inflammatory anergy despite avid phagocytic and bacteriocidal activity. J Clin Investig. 2005;115:66-75.

61. Konkel JE, Maruyama T, Carpenter AC, et al. Control of the development of CD8 $\alpha \alpha^{+}$intestinal intraepithelial lymphocytes by TGF- $\beta$. Nat Immunol. 2011;12:312-9.

62. Mennechet FJ, Kasper LH, Rachinel N, et al. Intestinal intraepithelial lymphocytes prevent pathogen-driven inflammation and regulate the Smad/T-bet pathway of lamina propria $\mathrm{CD}^{+}{ }^{+} \mathrm{T}$ cells. Eur J Immunol. 2004;34:1059-67.

63. Yang X, Letterio JJ, Lechleider RJ, et al. Targeted disruption of SMAD3 results in impaired mucosal immunity and diminished T cell responsiveness to TGF-beta. EMBO J. 1999;18:1280-91.

64. Oshima H, Nakayama M, Han TS, et al. Suppressing TGF $\beta$ signaling in regenerating epithelia in an inflammatory microenvironment is sufficient to cause invasive intestinal cancer. Cancer Res. 2015;75:766-76.

65. Biancheri P, Di Sabatino A, Corazza GR, et al. Proteases and the gut barrier. Cell Tissue Res. 2013;351:269-80.

66. Howe KL, Reardon C, Wang A, et al. Transforming growth factor-beta regulation of epithelial tight junction proteins enhances barrier function and blocks enterohemorrhagic Escherichia coli O157: H7-induced increased permeability. Am J Pathol. 2005;167:1587-97.

67. Biancheri P, Giuffrida P, Docena GH, et al. The role of transforming growth factor (TGF)- $\beta$ in modulating the immune response and fibrogenesis in the gut. Cytokine Growth Factor Rev. 2014;25:45-55.

68. Burke JP, Mulsow JJ, O'Keane C, et al. Fibrogenesis in Crohn's disease. Am J Gastroenterol. 2007;102:439-48.

69. Stallmach A, Schuppan D, Riese HH, et al. Increased collagen type III synthesis by fibroblasts isolated from strictures of patients with Crohn's disease. Gastroenterology. 1992;102: 1920-9.

70. Li G, Ren J, Hu Q, et al. Oral pirfenidone protects against fibrosis by inhibiting fibroblast proliferation and TGF- $\beta$ signaling in a murine colitis model. Biochem Pharmacol. 2016;117:57-67.

71. Speca S, Rousseaux C, Dubuquoy C, et al. Novel PPAR $\gamma$ modulator GED-0507-34 levo ameliorates inflammation-driven intestinal fibrosis. Inflamm Bowel Dis. 2016;22:279-92.

72. Kamada N, Seo SU, Chen GY, et al. Role of the gut microbiota in immunity and inflammatory disease. Nat Rev Immunol. 2013;13:321-35.

73. Furusawa Y, Obata Y, Fukuda S, et al. Commensal microbederived butyrate induces the differentiation of colonic regulatory T cells. Nature. 2013;504:446-50.

74. Atarashi K, Tanoue T, Shima T, et al. Induction of colonic regulatory $\mathrm{T}$ cells by indigenous Clostridium species. Science. 2011;331:337-41.

75. Atarashi K, Tanoue T, Oshima K, et al. Treg induction by a rationally selected mixture of Clostridia strains from the human microbiota. Nature. 2013;500:232-6.

76. Sokol H, Seksik P, Furet JP, et al. Low counts of Faecalibacterium prausnitzii in colitis microbiota. Inflamm Bowel Dis. 2009;15:1183-9. 
77. Seki H, Shiohara M, Matsumura T, et al. Prevention of antibiotic-associated diarrhea in children by Clostridium butyricum MIYAIRI. Pediatr Int. 2003;45:86-90.

78. Frank DN, St Amand AL, Feldman RA, et al. Molecular-phylogenetic characterization of microbial community imbalances in human inflammatory bowel diseases. Proc Natl Acad Sci USA. 2007;104:13780-5.

79. Round JL, Mazmanian SK. Inducible Foxp $3^{+}$regulatory T-cell development by a commensal bacterium of the intestinal microbiota. Proc Natl Acad Sci USA. 2010;107:12204-9.

80. Bloom SM, Bijanki VN, Nava GM, et al. Commensal Bacteroides species induce colitis in host-genotype-specific fashion in a mouse model of inflammatory bowel disease. Cell Host Microbe. 2011;9:390-403.

81. Carvalho FA, Koren O, Goodrich JK, et al. Transient inability to manage proteobacteria promotes chronic gut inflammation in TLR5-deficient mice. Cell Host Microbe. 2012;12:139-52.

82. Panday A, Sahoo MK, Osorio D, et al. NADPH oxidases: an overview from structure to innate immunity-associated pathologies. Cell Mol Immunol. 2015;12:5-23.

83. Kamdar K, Khakpour S, Chen J, et al. Genetic and metabolic signals during acute enteric bacterial infection alter the microbiota and drive progression to chronic inflammatory disease. Cell Host Microbe. 2016;19:21-31.

84. Hirata Y, Ihara S, Koike K. Targeting the complex interactions between microbiota, host epithelial and immune cells in inflammatory bowel disease. Pharmacol Res. 2016;113:574-84.

85. Monteleone G, Neurath MF, Ardizzone S, et al. Mongersen, an oral SMAD7 antisense oligonucleotide, and Crohn's disease. N Engl J Med. 2015;372:1104-13.

86. Monteleone G, Fantini MC, Onali S, et al. Phase I clinical trial of Smad7 knockdown using antisense oligonucleotide in patients with active Crohn's disease. Mol Ther. 2012;20:870-6.

87. Monteleone G, Di Sabatino A, Ardizzone S, et al. Impact of patient characteristics on the clinical efficacy of Mongersen (GED-0301), an oral Smad7 antisense oligonucleotide, in active Crohn's disease. Aliment Pharmacol Ther. 2016;43:717-24.

88. Feagan BG, Rutgeerts P, Sands BE, et al. Vedolizumab as induction and maintenance therapy for ulcerative colitis. N Engl J Med. 2013;369:699-710.

89. Kulkarni AB, Ward JM, Yaswen L, et al. Transforming growth factor-beta 1 null mice. An animal model for inflammatory disorders. Am J Pathol. 1995;146:264-75.

90. Seamons A, Treuting PM, Brabb T, Maggio-Price L. Characterization of dextran sodium sulfate-induced inflammation and colonic tumorigenesis in Smad3(-/-) mice with dysregulated TGF $\beta$. PLoS One. 2013;8:e79182.
91. Maggio-Price L, Treuting P, Bielefeldt-Ohmann H, et al. Bacterial infection of Smad3/Rag2 double-null mice with transforming growth factor-beta dysregulation as a model for studying inflammation-associated colon cancer. Am J Pathol. 2009;174:317-29.

92. Maggio-Price L, Treuting P, Zeng W, Tsang M, BielefeldtOhmann H, Iritani BM. Helicobacter infection is required for inflammation and colon cancer in SMAD3-deficient mice. Cancer Res. 2006;66:828-38.

93. Szigeti R, Pangas SA, Nagy-Szakal D, et al. SMAD4 haploinsufficiency associates with augmented colonic inflammation in select humans and mice. Ann Clin Lab Sci. 2012;42:401-8.

94. Hahm KB, Im YH, Parks TW, et al. Loss of transforming growth factor beta signalling in the intestine contributes to tissue injury in inflammatory bowel disease. Gut. 2001;49:190-8.

95. Beck PL, Rosenberg IM, Xavier RJ, Koh T, Wong JF, Podolsky DK. Transforming growth factor-beta mediates intestinal healing and susceptibility to injury in vitro and in vivo through epithelial cells. Am J Pathol. 2003;162:597-608.

96. Lucas PJ, Kim SJ, Melby SJ, Gress RE. Disruption of T cell homeostasis in mice expressing a $\mathrm{T}$ cell-specific dominant negative transforming growth factor beta II receptor. J Exp Med. 2000;191:1187-96.

97. Yang XO, Nurieva R, Martinez GJ, et al. Molecular antagonism and plasticity of regulatory and inflammatory $\mathrm{T}$ cell programs. Immunity. 2008;29:44-56.

98. Kim BG, Li C, Qiao W, et al. Smad4 signalling in T cells is required for suppression of gastrointestinal cancer. Nature. 2006;441:1015-19.

99. Zhang N, Bevan MJ. TGF- $\beta$ signaling to $\mathrm{T}$ cells inhibits autoimmunity during lymphopenia-driven proliferation. Nat Immunol. 2012;13:667-73

100. Fantini MC, Rizzo A, Fina D, et al. Smad7 controls resistance of colitogenic $\mathrm{T}$ cells to regulatory $\mathrm{T}$ cell-mediated suppression. Gastroenterology. 2009;136:1308-16. doi:10.1053/j.gastro. 2008.12.053.

101. Rizzo A, Waldner MJ, Stolfi C, et al. Smad7 expression in T cells prevents colitis-associated cancer. Cancer Res. 2011;71:7423-32

102. Laouar Y, Sutterwala FS, Gorelik L, Flavell RA. Transforming growth factor-beta controls $\mathrm{T}$ helper type 1 cell development through regulation of natural killer cell interferon-gamma. Nat Immunol. 2005;6:600-7

103. Sanjabi S, Flavell RA. Overcoming the hurdles in using mouse genetic models that block TGF-beta signaling. J Immunol Methods. 2010;353:111-4 